\title{
HISTOLOGICAL STRUCTURE OF THE MIDGUT OF HONEY BEES (APIS MELLIFERA L.) FED POLLEN SUBSTITUTES FORTIFIED WITH PROBIOTICS
}

\author{
Bożena Szymaś, Aleksandra Langowska, \\ Magdalena Kazimierczak-Baryczko \\ Institute of Zoology, Department of Apidology, Poznań University of Life Sciences, \\ Wojska Polskiego 71c, 60-635 Poznań, Poland, \\ e-mail: beszymas@up.poznan.pl
}

Received 14 July 2011; accepted 22 February 2012

$\mathrm{S}$ u m m a r y

The aim of this investigations was to assess morphological changes in the midgut epithelium of bees nourished with pollen substitute or pollen substitute enriched with a probiotic preparation. One-day old worker bees were kept in cages placed in a temperature controlled environment. During the two-week feeding period workers were fed beebread (control), pure pollen substitute or pollen substitute fortified with three different doses of probiotic preparations: Biogen or Trilac (experimental groups). The assessment of histological changes of the bee midgut was carried out in bees feed for 8 and 14 days. Slight changes in the epithelium as well as strong merocrine-type secretion were recorded in bees nourished pollen substitute supplemented with probiotic preparations. Differences were observed, primarily, in quantities of the developed peritrophic membranes. Their quantities were particularly high after 14 days of feeding with the pollen substitute fortified with probiotic preparations. The development of numerous peritrophic membranes could have contributed to better utilization of nutrients contained in feed and better condition of bees.

Keywords: honey bee feeding, probiotics, midgut, histological picture, peritrophic membranes.

\section{INTRODUCTION}

The midgut of the honey bee, also known as the stomach proper, is deprived of a chitinous lining and is, therefore, susceptible to poisonous substances (Bielenin and Ibek, 1980), pathogens (Gregorc and Bowen, 2000) or malnourishment (Szymaś, 1976, 1994; Szymaś and Przybył, 2007).

Degeneration of cell nuclei or their complete disintegration and severe cytoplasm vacuolisation indicate changes in the midgut epithelium (Bielenin and Ibek, 1980). The presence of considerable quantities of peritrophic membranes in insects is associated with the duration of feeding (Crailsheim, 1988), presence of probiotic bacteria (Szymaś and Przyby1, 2007) or with the protection of the epithelium from harmful substances (Bielenin and Ibek, 1980; Lehane, 1997; Tellam et al., 1999).
The beneficial properties of probiotic preparations, confirmed in Man and other higher animals, has resulted in their use as an additive to protein-based pollen substitutes for the honey bee (KazimierczakBaryczko and Szymaś, 2006) and has contributed to the creation of appropriate and stable bacterial environment in the bee gut (Kaznowski et al., 2005).

The objective of this research project was to assess morphological changes in the midgut epithelium of bees nourished by pollen substitutes with and without probiotic enrichment.

\section{MATERIALS AND METHODS}

The investigations were carried out on workers of the honey bee (Apis mellifera carnica L.). One-day old bees emerged in an incubator were transferred into 40 small cages measuring $70 \mathrm{~mm}$ x $80 \mathrm{~mm}$ x $120 \mathrm{~mm}$. These cages were kept in a 
thermostatically controlled environment with the temperature maintained at $31^{\circ} \mathrm{C}$ and relative humidity at $40 \%$. Eight feeding groups were established with 5 cages per group and 150 bees per cage. Throughout the two week feeding period the control group bees were fed ad libitum naturally, i.e. beebread, and experimental groups received pollen substitute or pollen substitute enriched with probiotic preparations each at three different doses.

The pollen substitute was prepared from the following raw materials: potato protein (32\%), soybean meal $(18 \%)$, rapeseed meal $(6 \%)$, Candida utilis yeasts $(6 \%)$, wheat flour $(14.8 \%)$, maize grits $(17.5 \%)$, soybean oil $(3.5 \%)$, lecithin $(0.5 \%)$, Polfamix W (1.4\%), Vitazol AD3EC $(0.2 \%)$ and glucose with vitamin C $(0.1 \%)$. Soybean and rapeseed meals were subjected to the extrusion process, yeasts, wheat flour and maize grits were mixed with the addition of $4 \%$ water and subjected to micronisation (for 40 seconds in a microwave of $1000 \mathrm{~W}$ power). The experimental pollen substitute was then acidified with lactic acid to $\mathrm{pH}=4.0$. The feed was then pulverised in an impact mill to obtain particles of $150 \mu \mathrm{m}$ in diameter and mixed with powdered sugar at 1:1 weight ratio to achieve protein levels similar to those found in bee bread. The total protein content in bee bread and the pollen substitute was $21 \%$.

The following two probiotic preparations were used in the experiments: Biogen- $\mathrm{N}$ (purchased from the Enterprise of Biotechnology and Genetic Engineering Implementation and Application 'BIO-GEN' Ltd. in Opole and manufactured for piglets, calves and kids in their early development) and Trilac (from the Pharmacia \& Upjohn Allergon AB Ängelholm Company distributed by the Apiary-Pharmaceutical Enterprise "APIPOL-FARMA" Ltd. produced for human consumption). The Biogen-N preparation was modified for this experiment and no lactose or microand macro-elements were used in its composition.
Both preparations were fed in three doses. Biogen- $\mathrm{N}$ was fed in the following quantities: $0.5 \mathrm{mg}, 1 \mathrm{mg}$ and $2 \mathrm{mg}$ per $100 \mathrm{~g}$ of pollen substitute, and Trilac: $0.724 \mathrm{~g}$, $1.267 \mathrm{~g}$ and $2.534 \mathrm{~g}$ per $100 \mathrm{~g}$ of pollen substitute. Total bacterial counts in the $1 \mathrm{mg}$ Biogen-N and $1.267 \mathrm{~g}$ of Trilac doses were similar and amounted to $11 \times 10^{9}$.

Evaluation of histological changes of the bee midgut epithelium was carried out in bees fed for 8 and 14 days. One bee was randomly selected from each cage, i.e. 5 midguts were examined per every single experimental group ( 80 bees, total). Tissue samples were fixed in $4 \%$ buffered formalin for 24 hours, and then dehydrated in graded ethyl alcohols, cleared in xylene, and embedded in paraffin. Afterwards, tissue specimens were cut into $4 \mu \mathrm{m}$ thick sections and mounted on glass slides and dried. After deparaffination in xylene and rehydrated in graded ethyl alcohols sections were stained with Mayer's hematoxylin and eosin. Thereafter slides were once more dehydrated with alcohol, cleared through 3-4 changes of xylene, and coversliped in Histokitt. Preparations were examined upon an Axioplan 2e light microscope which provided magnifications ranging from $50 \mathrm{x}$ to $400 \mathrm{x}$.

\section{RESULTS}

In bees fed for 8 days with bee bread (Fig. 1), it was found that the midgut epithelium was higher in some places, cell cytoplasm grained and sometimes vacuolized at the base with lighter areas ('hallos') around nuclei. Nuclei were of high stainability, while rabdorium and regeneration crypts looked normal. Peritrophic membranes were visible, intestinal lumen slightly widened and holoand merocrine secretion distinctly marked. In bees fed for 14 days with bee bread (Fig. 2), the microscopic image showed a similar picture in cell epithelium as in bees fed for 8 days, however with the exception of cytoplasm vacuolisation at the basement membrane which was greater. Pollen grains surrounded by peritrophic membranes were visible in the intestinal lumen. 


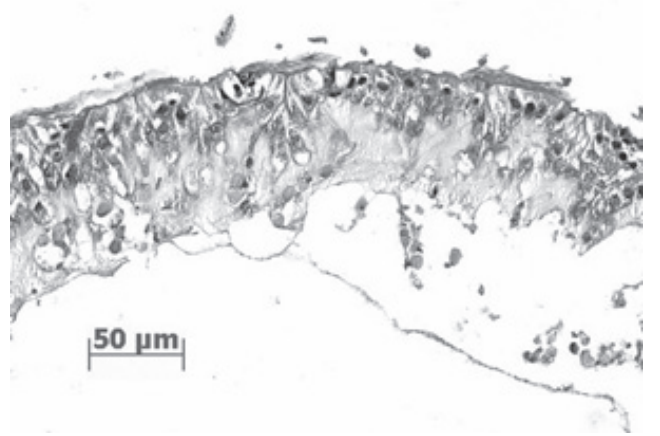

Fig. 1 Microscopic image of the bee midgut nourished with bee bread for the period of 8 days. Excessively stainable cell nuclei. Stained with H\&E.

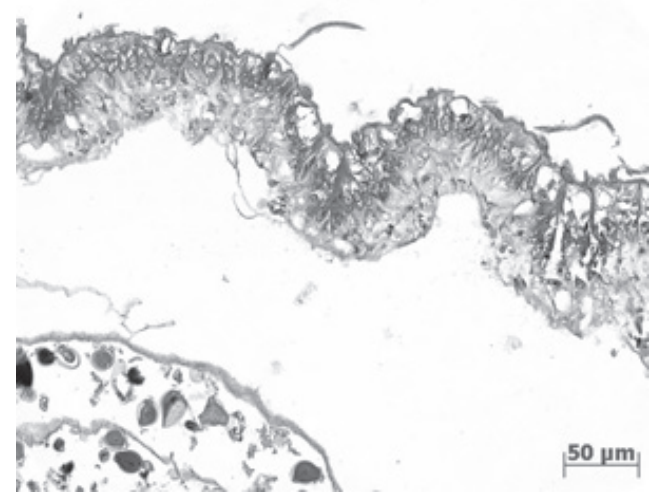

Fig. 2. Midgut epithelium of a bee fed bee bread for 14 days. Cytoplasm vacuolization visible in places. Flower pollen grains wrapped in peritrophic membranes can be seen in the gut lumen. Stained with H\&E.

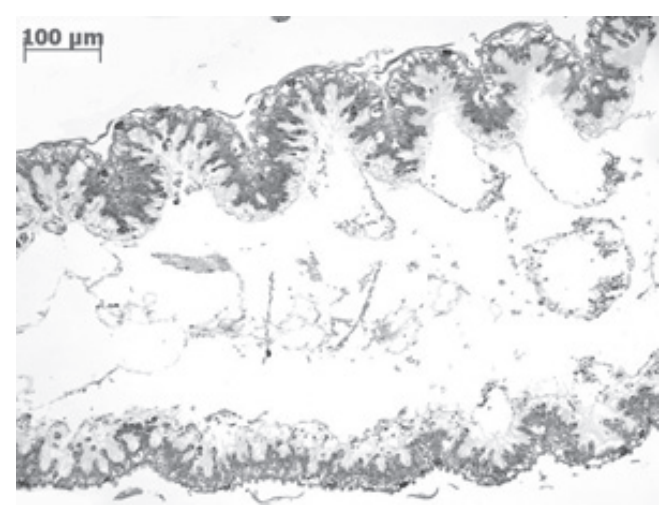

Fig. 3. Microscopic image of the bee midgut nourished with pollen substitute for the period of 8 days. Cell cytoplasm near basic membrane vacuolized. Stained with H\&E. 


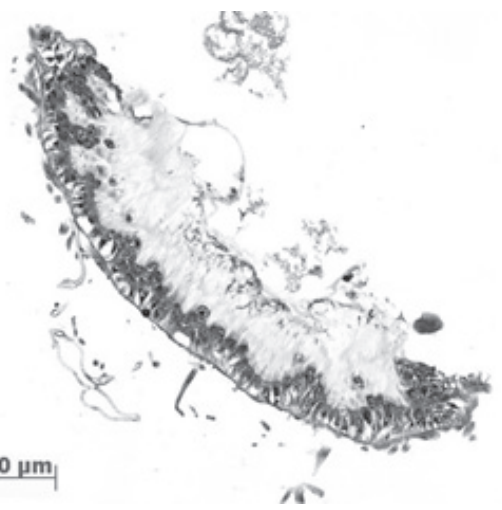

Fig. 4. Microscopic image of the bee midgut nourished with pollen substitute for the period of 14 days. Considerable stainability of cell nuclei. Stained with H\&E.

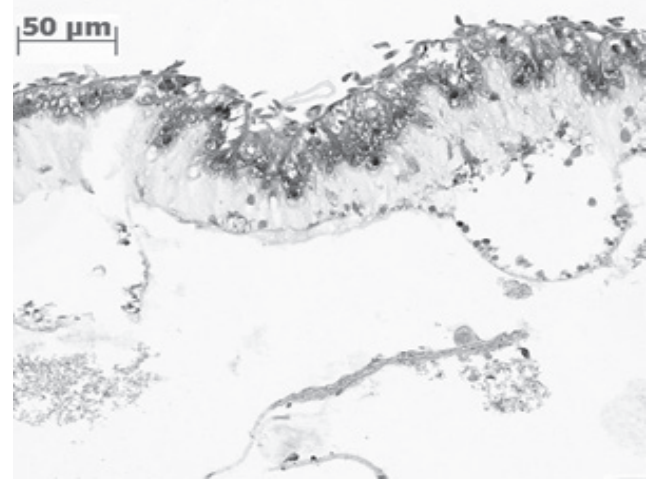

Fig. 5. Midgut epithelium of a bee fed pollen substitute fortified with Biogen-N probiotic preparation ( $1 \mathrm{mg} / 100 \mathrm{~g}$ feed) for 8 days. Excessively stainable cell nuclei. Strong merocrine type secretion. Stained with H\&E.

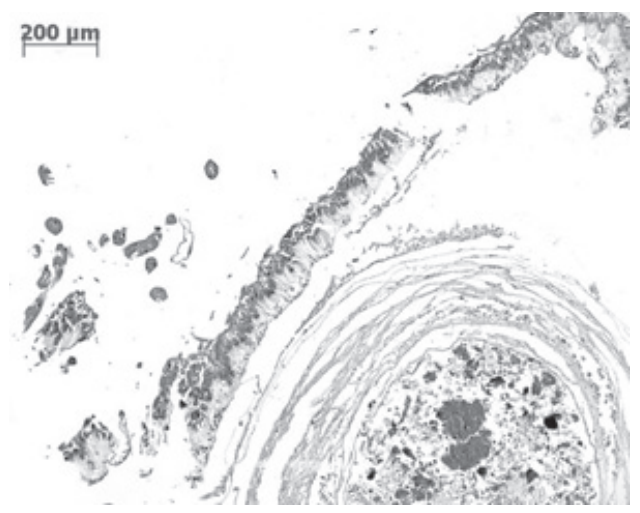

Fig. 6. Microscopic image of bee midgut nourished for 14 days pollen substitute fortified with Biogen-N probiotic preparation ( $1 \mathrm{mg} / 100 \mathrm{~g}$ feed). Very numerous peritrophic membranes. Stained with $H \& E$. 
Figure 3 presents changes in the midgut epithelium of bees nourished with pollen substitute for 8 days. Rabdorium and peritrophic membranes were intact and cytoplasm was vacuolized at the base. At the end of the 14 day feeding period (Fig. 4), significant stainability was observed of nuclei which, in some cells, were hyperchromatic and the epithelium was depressed in some places.

The picture of changes in the midgut epithelium following the supplementation of the pollen substitute with the lowest doses of probiotic preparations, i.e. $0.5 \mathrm{mg}$ of Biogen-N or $0.724 \mathrm{~g}$ of Trilac, was similar to that of bees fed with the plain pollen substitute.

Figure 5 shows the results of feeding bees with pollen substitute supplemented with $1 \mathrm{mg}$ Biogen-N for 8 days. The epithelium was high, cytoplasm slightly vacuolized (especially at the base), tearing off the peritrophic membrane from the epithelium was clearly visible; merocrinetype secretion was marked strongly, while holocrine secretion was milder. When feeding this diet for 14 days, homogenic masses surrounded by very numerous peritrophic membranes occurred in the intestinal lumen (Fig. 6).

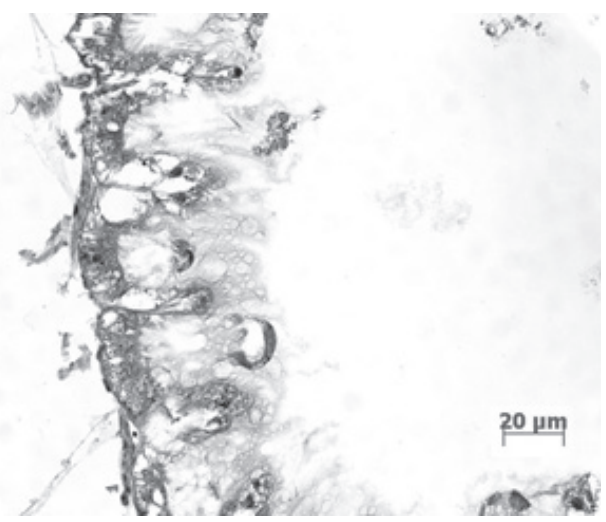

Fig. 7. Midgut epithelium of a bee fed pollen substitute fortified with Trilac preparation $(1.267 \mathrm{~g} / 100 \mathrm{~g}$ feed) for 8 days. Significant vacuolization of cytoplasm in places. Strongly marked merocrine type secretion. Stained with H\&E.

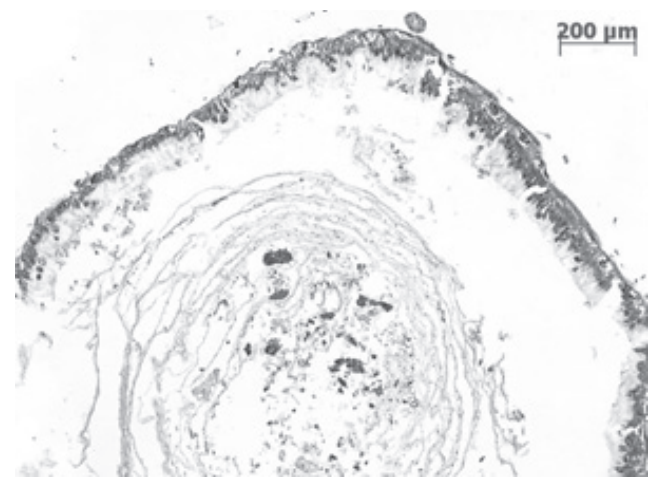

Fig. 8. Cross section of a bee midgut fed pollen substitute fortified with Trilac preparation $(1.267 \mathrm{~g} / 100 \mathrm{~g}$ feed) for 14 days.

Numerous peritrophic membranes, gut lumen widened. Stained with H\&E. 
Figure 7 presents the picture of the stomach epithelium of bees nourished with diets containing $1.267 \mathrm{~g}$ of Trilac. Changes were observed, primarily, in the cytoplasm which was strongly vacuolized in some places. Regeneration crypts, distinct cell nuclei, prominent rabdorium and strong merocrine secretion were found to occur. Changes in the intestinal epithelium of bees fed for two weeks were similar to those fed for 8 days and only the lumen of the intestine was slightly enlarged and a distinct increase in numbers of peritrophic membrane became apparent (Fig. 8).

Changes in the intestines found in bees nourished with the pollen substitute supplemented with the highest doses of Biogen-N (2 mg) and Trilac (2.534 g) were similar to those recorded with the relevant intermediate dose.

\section{DISCUSSION}

The use of probiotic preparations as additives to substitute feeds in bee nutrition still remain at the experimental stage. Łangowska et al. (2003), Kaznowski et al. (2005) and KazimierczakBaryczko and Szymaś (2006) reported that the addition of probiotic preparations to protein substitute feeds improved the utilization of feed constituents as evidenced by better condition of bees, confirmed by fewer deaths, better developed fat body and pharyngeal glands or higher dry matter content of the body.

Feeding bees substitute feeds, in particular pollen substitutes, which may turn out to be less readily digestible, may lead to the development of changes in the epithelial structure of the midgut (Szymaś, 1976, 1994). In our experiment no significant degeneration of the epithelial structure was observed following the feeding of bees with pollen substitute in comparison with the natural diet based on bee bread. In bees fed for both 8 and 14 days, the centres of cell proliferation (regeneration crypts), cell nuclei as well as the rabdorium remained unchanged. The greatest changes concerned cytoplasm, which was to a lesser or greater extent vacuolized, most frequently in the neighbourhood of the basement membrane. Nevertheless, no complete cytoplasm vacuolisation was observed. Complete cytoplasm vacuolisation would indicate cell deformations of the lining epithelium (Bielenin and Ibek, 1980) but such strong changes did not take place in this investigation. In this study, thehistological image of the midgut of worker honey bees fed for 14 days with pollen substitute fortified by probiotic preparations revealed the presence of considerable quantities of peritrophic membranes. Szymaś and Przybył (2007) also reported higher quantities of peritrophic membranes in the stomach of bees after supplementation of sugar syrup and pollen substitute with probiotic preparations. According to Bolognesi et al. (2008) peritrophic membranes enhance digestive efficiency by a few mechanisms. In bees, high quantities of peritrophic membranes are associated with the duration of feeding (Crails heim, 1988). The consumed food can stay longer in the intestine and can be utilised better by the organism. The above conclusions was confirmed in our investigation. Our experiment used the same feed composition as Kazimierczak-Baryczko and Szymaś (2006) which confirmed a significant influence of probiotic preparations on the condition of bees.

The observed expansion of the intestinal lumen in bees, in particular in those which were fed bee bread, indicated flatulence. This condition could have been caused by the presence in the feed of substances causing gas secretion (Szymaś, 1994) or with the presence of mineral compounds. Crailsheim and Pabst (1988) proved that mineral compounds in honey, even in small quantities, cause flatulence of the midgut and bursting of peritrophic membranes takes place after 6 days of feed intake. Undoubtedly, mineral substances contained in bee bread and pollen substitute could have led to the expansion of the intestinal lumen.

Our investigations confirmed strong merocrine and weaker holocrine secretions in the epithelial cells lining the intestine 
in the majority of bees nourished with the experimental pollen substitute as well as pollen substitute enriched with probiotic preparations. There was no cell break up in the merocrine-type secretion and cells could secrete enzymes through the rabdorium layer in the form of small bubbles. This form of secretion, which occurs most frequently in insects ( $\mathrm{J}$ im enez and Gilliam, 1990) was confirmed here.

\section{CONCLUSIONS}

The histological analysis of the morphological changes of the midgut epithelium of bees fed pollen substitute fortified with probiotic preparations confirmed slight differences in cell structures when compared to the epithelium of bees fed bee bread.

Strong merocrine-type secretion as well as greater quantities of peritrophic membranes were observed in bees on the diet fortified with probiotic preparations.

\section{ACKNOWLEDGMENTS}

We would like to thank Tim Sparks for linguistic corrections and the reviewers of the manuscript for their comments and suggestions.

\section{REFERENCES}

Bielenin I., Ibek Z. (1980) - Wpływ fluorku sodu na nabłonek jelita środkowego pszczoły miodnej, Apis mellifera L. (Apidae, Hymenoptera).[Influence of sodium fluoride on midgut epithelium of honey bee, Apis mellifera L. - in Polish] Zeszyty Naukowe AR Kraków, 159(20): 49-67.

Bolognesi R., Terra W. R., Ferreira C. (2008) - Peritrophic membrane role in enhancing digestive efficiency: Theoretical and experimental models. J. Insect Physiol., 54(10-11): 1413-1422.

Crailsheim K. (1988) - Transport of leucine in the alimentary canal of the honeybee (Apis mellifera L.) and its dependence on season. J. Insect Physiol., 34(12):1093-1100.
Crailsheim K., Pabst M. A. (1988) - Der Einfluss von Honig mit hohem Mineralstoffgehalt auf die Sterblichkeit und das Mitteldarm gewebe der Honigbiene (Apis mellifera carnica Pollm) im Winter. Mitt. dtsch. Ges. allg. angew. Ent., 6(2): 125-135.

Gregorc A., Bowen I. D. (2000) Histochemical characterization of cell death in honeybee larvae midgut after treatment with Paenibacillus larvae, amitraz and oxytetracycline. Cell Biology International, 24(5): 319-324.

Jimenez D. R., Gilliam M. (1990) - Ultrastructure of the ventriculus of the honey bee (Apis mellifera L.): cytochemical localization of amid phosphatase, alkaline phosphatase and nonspecific esterase. Cell Tissue Res., 261: 431-443.

Kazimierczak-Baryczko M., Szymaś B. (2006) - Improvement of the composition of pollen substitute for honey bee (Apis mellifera L.) through implementation of probiotic preparations. J. Apic. Sci., 50(1): 15-23.

Kaznowski A., Szymaś B., Gaździńska E., Kazimierczak M., Paetz H. (2005) - The effect of probiotic supplementation on the content of intestinal microflora and chemical composition of worker honey bees (Apis mellifera L.). J. Apic. Res., 44(1): 10-14.

Lehane M. J. (1997) - Peritrophic matrix structure and function, Annu. Rev. Entomol., 42: 525-550.

Łangowska A., Szymaś B., Baryczko M. (2003) - Laboratory evaluation of proteinaceous feed for bees containing lactic acid bacteria. Scient. Pap. Agric. Univ. Poznań. Animal Sci., 5: 53-61.

Szymaś B. (1976) - Histologiczna ocena zmian nabłonka jelita środkowego pszczół miodnych żywionych namiastkami pyłku. [Histological examination of changes in midgut epithelium of honey bees fed pollen substitutes - in Polish] Rocz. AR Pozn. 88, Zootechnika, 22: 141-147. 
Szymaś B. (1994) - Ocena wartości odżywczej surogatów pyłku kwiatowego dla pszczoły miodnej (Apis mellifera L.). [Evaluation of the nutritive value of pollen substitute for honey bee (Apis mellifera L.) - in Polish] Rocz. AR Pozn., Rozprawy Naukowe pp. 68.

Szymaś B., Przybył A. (2007) - Midgut histological picture of the honey bee (Apis mellifera L.) following consumption of substitute feeds supplemented with feed additives. Nauka Przyroda Technologie, 1, 4 \#48.
Tellam R.L., Wijffels G., Willadsen P. (1999) - Peritrophic matrix proteins. Insect Biochem. Mol. Biol., 29: 87-101.

\title{
OBRAZ HISTOLOGICZNY JELITA ŚRODKOWEGO PSZCZÓL (APIS MELLIFERA L.) ŻYWIONYCH NAMIASTKAMI PYLKU KWIATOWEGO WZBOGACONYMI PROBIOTYKAMI
}

\author{
Szymaś B., Langowska A., \\ Kazimierczak-Baryczko M.
}

S t r e s z c z e n i e

Celem badań była ocena zmian morfologicznych w nabłonku jelita środkowego pszczół żywionych namiastką pyłku oraz namiastką wzbogaconą preparatami probiotycznymi.

Jednodniowe pszczoły robotnice przetrzymywano w małych ulikach umieszczonych w cieplarkach. Przez cały, trwający dwa tygodnie, okres żywieniowy, robotnice z grupy kontrolnej otrzymywały pierzgę, a pszczoły z grup doświadczalnych „czystą” namiastkę i namiastkę wzbogacona preparatem probiotycznym Biogen lub Trilac. Preparaty podano w trzech dawkach tak, aby ogólna liczba bakterii w kolejnej dawce obu preparatów była jednakowa: Biogen-N w ilości $0,5 \mathrm{mg}, 1 \mathrm{mg}$ i $2 \mathrm{mg}$ na $100 \mathrm{~g}$ namiastki, a Trilac $0,724 \mathrm{~g}, 1,267 \mathrm{~g}$ i 2,534 g na $100 \mathrm{~g}$ namiastki. Ocenę zmian histologicznych nabłonka jelita środkowego pszczół przeprowadzono 8 i 14 dnia żywienia. Odnotowano nieznaczne zmiany w strukturach komórkowych oraz silną sekrecję typu merokrynowego u osobników spożywających namiastkę wzbogaconą preparatami probiotycznymi. Różnice stwierdzono przede wszystkim w liczbie powstałych błon perytroficznych. Szczególnie dużą ich liczbę stwierdzono po 14 dniach spożywania namiastki pyłku kwiatowego wzbogaconej preparatami probiotycznymi. Wytworzenie licznych błon perytroficznych mogło przyczynić się do lepszego wykorzystania składników pokarmowych paszy.

Słowa kluczowe: żywienie pszczoły miodnej, probiotyki, jelito środkowe, obraz histologiczny, błony perytroficzne. 